Available online on $\mathbf{1 5 . 0 5 . 2 0 1 6}$ at http://jddtonline.info
Journal of Drug Delivery and Therapeutics
An International Peer Reviewed Journal
Open access to Pharmaceutical and Medical research
¿ 2016, publisher and licensee JDDT, This is an Open Access article which permits unrestricted noncommercial use, provided the original
work is properly cited

\title{
PHYSICIAN AND PHARMACIST OPINION ON DIABETES MELLITUS AND THE MOST COMMONLY PRESCRIBED ANTI-DIABETIC DRUG IN VARIOUS DISTRICTS OF U.P. (WEST), INDIA
}

\author{
Rastogi Vaibhav $^{1 *}$, Kumar Bhaskar ${ }^{1}$, Kumar Deepak $^{1}$, Kumar Arvind ${ }^{1}$, Porwal Mayur ${ }^{1}$, Yadav Pragya ${ }^{1}$, Prasad \\ Neelkant $^{1}$, Rastogi Pallavi $^{2}$
}

${ }^{1}$ Faculty of Pharmacy, IFTM University, Lodhipur Rajput, Delhi Road (NH-24) Moradabad- 244001 (UP), India

${ }^{2}$ Department of Mathematics, Hindu College, Station Road, Moradabad (U.P.) 244001, India

Received 22 March 2016; Review Completed 17 April 2016; Accepted 19 April 2016, Available online 15 May 2016

\begin{abstract}
Diabetes mellitus (DM) is a group of metabolic disorders characterized by a chronic hyperglycemic condition resulting from defects in insulin secretion, insulin action or both. The prevalence of diabetes is increasing rapidly worldwide and the World Health Organization indicates global prevalence of diabetes was estimated to be $9 \%$ among adults aged $18+$ years and it will be the 7th leading cause of death in 2030. The aim of this paper is to gather latest information on the prevalence of Diabetes among the human society and also to investigate pharmaceutical marketing of Metformin and its combinations used for Diabetes Mellitus in various districts of U.P. (West) region. The survey was based on the questionnaire which was presented before the physicians and the pharmacist in-charge on medical store to get information about the patient having diabetes mellitus and commonly prescribed brands of Metformin alone and its combination with other anti-diabetic drugs. On the basis of physician's opinion on the Diabetes (type 2), $65.78 \%$ of patients from total OPD patients was found to have diabetes, $49.76 \%$ patients are type- 2 patients, $7.45 \%$ of teenagers was fall in the category of having type- 1 diabetes and $8.57 \%$ were among the new patients of diabetes. There are 20 and 30 brands in Metformin (and its HCl salt), Metformin (and its $\mathrm{HCl}$ salt) with other anti-diabetic drug categories, respectively. The sale of Glyciphage of Franco Indian Remedies brand of the Metformin only, Diapride M 1 containing Glimepiride and Metformin $500 \mathrm{mg}$ from Micro Labs Ltd., respective categories, were highest in the area of interest.
\end{abstract}

Keywords: Diabetes Mellitus, Metformin (and its $\mathrm{HCl}$ salt), Combination drugs, Marketing Investigation.

\section{INTRODUCTION}

"Man may be the captain of his fate, but he is also the victim of his blood sugar" said by Dr. Wilfred Oakley 1 .

The prevalence of diabetes in $21^{\text {st }}$ century is increasing due to diet changes, aging, urbanization, and increasing prevalence of obesity and physical inactivity. King et al., 1998 predicted a rise in global diabetes prevalence to $5.4 \%$ of the world population by the year $2025(27 \%$ increase in developed countries and $48 \%$ increase in developing countries) ${ }^{2}$. In 2000, there were 171 millions of people having diabetes in the world; 2006 was 246 million people. It was estimated that in 2025 , there would be 380-399 million people having diabetes 3 . According to an estimate of International Diabetes Federation comparative prevalence of Diabetes during 2007 is $8.0 \%$ and likely to increase to $7.3 \%$ by 2025 . Number of people with diabetes is 246 million (with $46 \%$ of all those affected in the 40-59 age group) and likely to increase to 380 million by $2025^{4}$. The World Health Organization believes that the $21^{\text {st }}$ century is the time of endocrine diseases and metabolic disorders, for example, diabetes. In over the world, people have to spend 232 billion to 430 billion USD for diabetes treatments and prevention. Diabetes reduces 5-10 years of human life expectancy. In 2014, the World Health Organization indicates global prevalence of diabetes was estimated to be $9 \%$ among adults aged 18+ years and it will be the 7 th leading cause of death in $2030^{5-7}$.

Diabetes is a metabolic disorder caused by many reasons. It is characterized by chronic hyperglycemia and metabolic disorders of sugar, protein, fat caused by the deficiency of insulin secretion, the insulin activities, or both. Pathophysiology of type 2 and 1 Diabetes Mellitus is explained in the Fig. 1 and Fig. 2 respectively ${ }^{8}$.

"Corresponding Author Vaibhav Rastogi

Faculty of Pharmacy, IFTM University, Moradabad, Uttar Pradesh, 244001, India Phone: $+91-9457041148$ E-mail: vaib.asa@gmail.com 


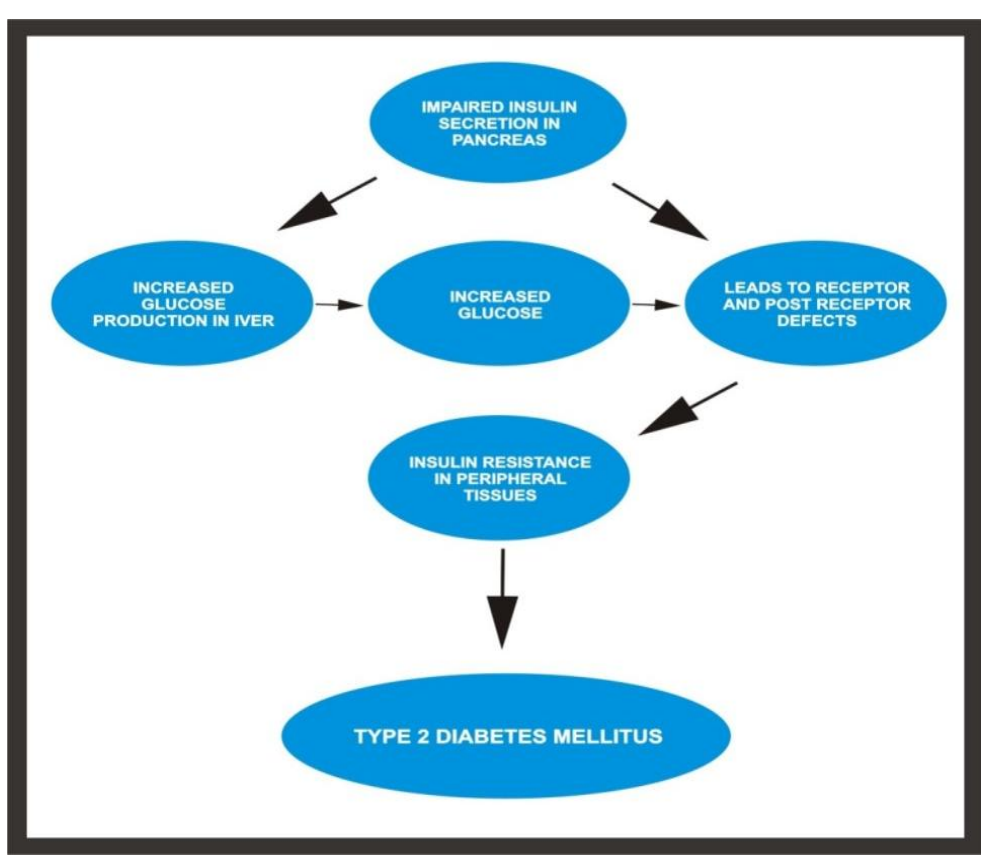

Figure 1: Pathophysiology of Type 2 Diabetes Mellitus

Pharmaceutical marketing, sometimes called medico-marketing or pharma marketing in some countries is the business of advertising or otherwise promoting the sale of pharmaceuticals or drugs [9]. Pharmaceutical detailing is a marketing technique used by pharmaceutical companies to educate a physician about a vendor's products in hopes that the physician will prescribe the company's products more often. Although this practice is controversial, many drug companies spend billions of dollars a year on this legal tactic. In the United States, marketing and distribution of pharmaceuticals is regulated by the Federal Food, Drug, and Cosmetic Act and the Prescription Drug Marketing Act, respectively. Food and Drug Administration (FDA) regulations require all prescription drug promotion to be truthful and not misleading, based on "substantial evidence or substantial clinical experience", to provide a "fair balance" between the risks and benefits of the promoted drug, and to maintain consistency with labeling approved by the FDA. The FDA Office of Prescription Drug Promotion enforces these requirements ${ }^{9}$.

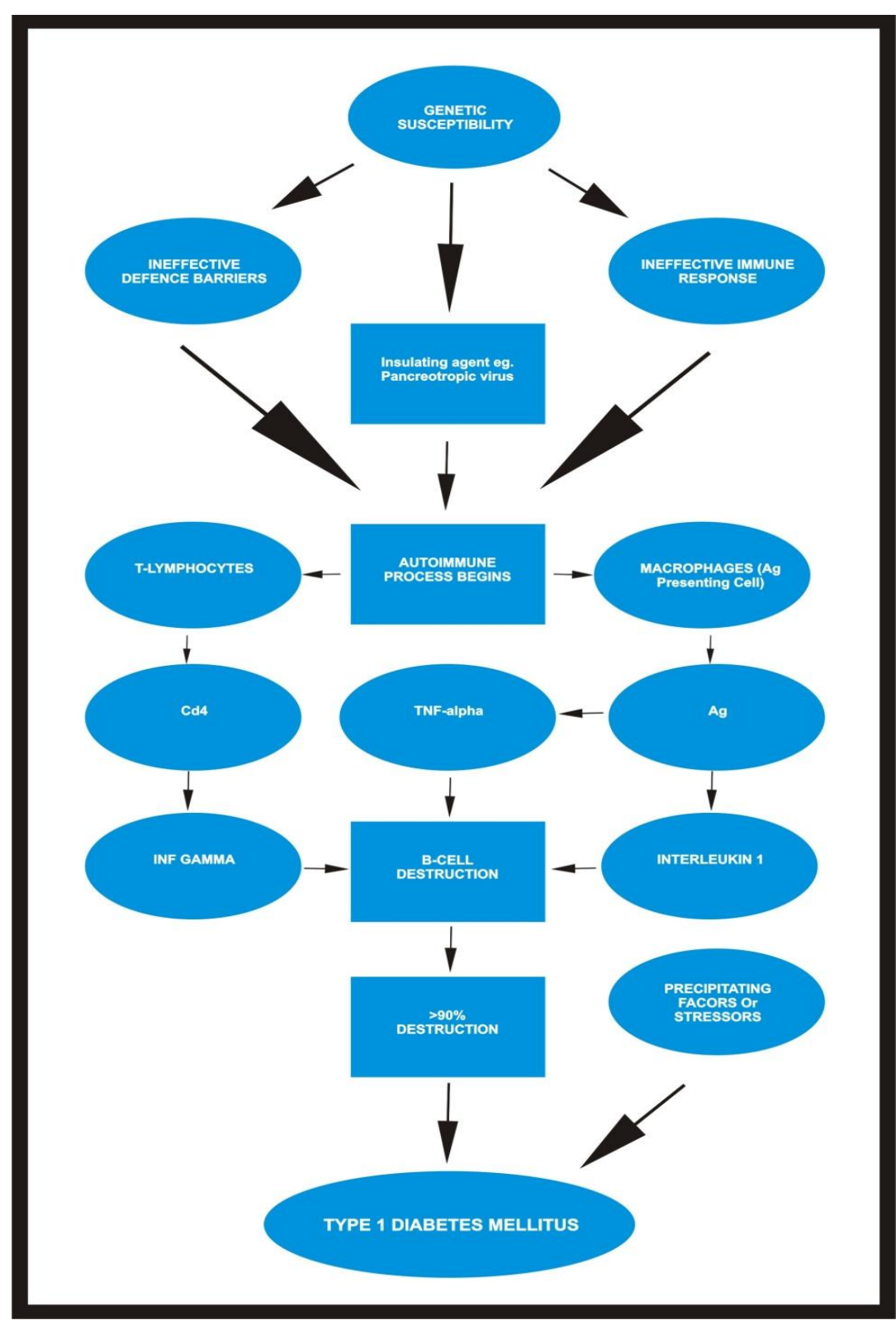

Figure 2: Pathophysiology of Type 1 Diabetes Mellitus 
It was long believed that since physicians made the selection of drugs, mass marketing was a waste of resources; specific advertisement targeting the medical profession were thought to be cheaper and just as effective. This would involve advertisement in professional journals and visits by sales staff to physician's offices and hospitals. An important part of these efforts was marketing to medical students ${ }^{10}$. On the basis of this background, we made pharmaceutical marketing investigation of Metformin and its combinations used for Diabetes Mellitus in Moradabad, Rampur, Bareilly and Meerut districts of U.P. (West).

Pharmaceutical marketing, sometimes called medicomarketing or pharma marketing in some countries is the business of advertising or otherwise promoting the sale of pharmaceuticals or drugs [9]. Pharmaceutical detailing is a marketing technique used by pharmaceutical companies to educate a physician about a vendor's products in hopes that the physician will prescribe the company's products more often. Although this practice is controversial, many drug companies spend billions of dollars a year on this legal tactic. In the United States, marketing and distribution of pharmaceuticals is regulated by the Federal Food, Drug, and Cosmetic Act and the Prescription Drug Marketing Act, respectively. Food and Drug Administration (FDA) regulations require all prescription drug promotion to be truthful and not misleading, based on "substantial evidence or substantial clinical experience", to provide a "fair balance" between the risks and benefits of the promoted drug, and to maintain consistency with labeling approved by the FDA. The FDA Office of Prescription Drug Promotion enforces these requirements ${ }^{9}$.

It was long believed that since physicians made the selection of drugs, mass marketing was a waste of resources; specific advertisement targeting the medical profession were thought to be cheaper and just as effective. This would involve advertisement in professional journals and visits by sales staff to physician's offices and hospitals. An important part of these efforts was marketing to medical students 10 . On the basis of this background, we made pharmaceutical marketing investigation of Metformin and its combinations used for Diabetes Mellitus in Moradabad, Rampur, Bareilly and Meerut districts of U.P. (West).

\section{MATERIALS AND METHODS}

This study was depended on a cross-sectional survey design and was conducted by administering a validated questionnaire to physicians and pharmacist on medical store of Moradabad, Rampur, Bareilly and Meerut districts of U.P. (West) on metformin and its combination drugs. Since this study was carried out during April 2015- April 2016, the sample size consisted of 10 Physicians and 10 pharmacist incharge of medical store in the districts (Moradabad, Rampur, Bareilly, Meerut) of U.P.(West) region which will tend to reflect the population size. Both physician as well as pharmacist was informed with the objectives of the study, and they were considered consented to participate in the survey.

\section{Study Instrument:}

A questionnaire (Table 1) was designed to collect information on Diabetes mellitus from the physicians. Another questionnaire (Table 2) was prepared for collecting information from pharmacists on medical stores. Both questionnaires were initially validated by two senior faculty members for content before data collection.

\section{RESULTS AND DISCUSSION}

\section{Physician Opinion:}

The objective of the study was to conduct and analyze a survey regarding the status of diabetes mellitus-2 among the people of various districts of U.P. west region of India.

Being diagnosed with diabetes is a major life stress and therefore it requires dealing with psychological challenges (grief, denial, anxiety, depression, shame and guilt). Various aspects of life associated diabetes that may affect quality of life include:

- The never-ending demands of diabetes care, such as eating carefully, exercising, monitoring blood glucose, and scheduling and planning

- Symptoms of low or very high blood glucose

- Fears about or the reality of complications

The specific things each person needs to feel satisfied and happy are unique to him or her. Still, there are some things most people would agree are important. Your quality of life is your own sense of how satisfied and happy you are with your life in general and your life with diabetes in particular. Many diabetes health care professionals are trained to help their patients adjust treatment regimens to ease the burden of diabetes management while maintaining good blood glucose control and good health. These providers may also be able to help you improve your day-to-day diabetes coping skills.

The data obtained after conducting the survey was drastically modified in comparison to the survey reported by Phool et al., (2013) ${ }^{11}$. In 2013, there were around $46.48 \%$ patients having diabetes and in 2015 the numbers are increased to $65.78 \%$. The major outcome was found among the teenagers, $7.45 \%$ of teenagers are having type- 1 diabetes. After consulting with the medical practitioner, the sole reason of having these disorders was found to be the improper nutritious diet taking and the magnetic effect of junk food, no physical exercise, increased mental stress, environmental toxins, etc, all these factors directly or indirectly linked to insulin resistance (a condition in which the body's muscle, fat, and liver cells do not use insulin effectively to counter the raised blood glucose level and resulted into diabetes).

Physician opinions on the questionnaire about the Diabetes (type-1 \& -2) are shown in the Fig. 3. 65.78\% 
of patients from total OPD patients were found to have diabetes, $49.76 \%$ patients are type- 2 patients, $7.45 \%$ of teenagers were fall in the category of having type- 1 diabetes and $8.57 \%$ were among the new patients of diabetes. Among various anti-diabetic drugs, Metformin, an oral antidiabetic drug in the biguanide class is the first-line drug of choice for the treatment of type-2 diabetes in particular, in overweight and obese people and those with normal kidney function, while Insulin become the primary drug of choice for type-1 Diabetic patients.

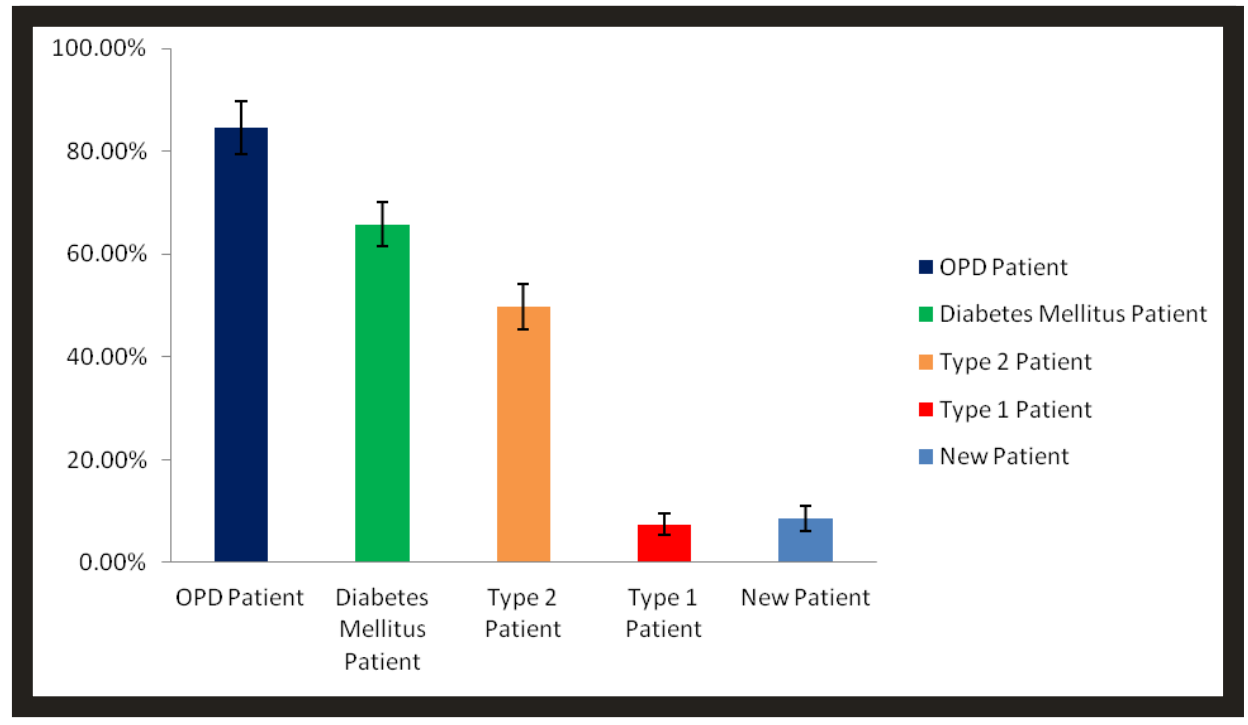

Figure 3: Physicians opinion on different type of patients

\section{Pharmacist in-charge report:}

There are 20 brands containing Metformin and its Hydrochloride salt found majorly in the market are mentioned in appendix 2 (Table 2). The sale of Glyciphage of Franco Indian Remedies brand containing Metformin only was higher among all other medicine and the sale was $22 \%$ of the total market and results are shown in the Fig. 4. Apart from the only metformin brand there are 30 brands of metformin (\& its $\mathrm{HCl}$ salt) in combination with other anti-diabetics drugs found majorly in the market are listed in Appendix 3 (Table 3). The investigation results produced the highest sale of Diapride M 1 containing Glimepiride and Metformin of Micro Labs Ltd. The sale was $35 \%$ and presented in Fig. 5. None of the pharmacist was agreed to sell metformin without prescription of physician. This reveals the great collaboration of pharmacist and physician to follow the rules laid by the FDA and the Central Government.

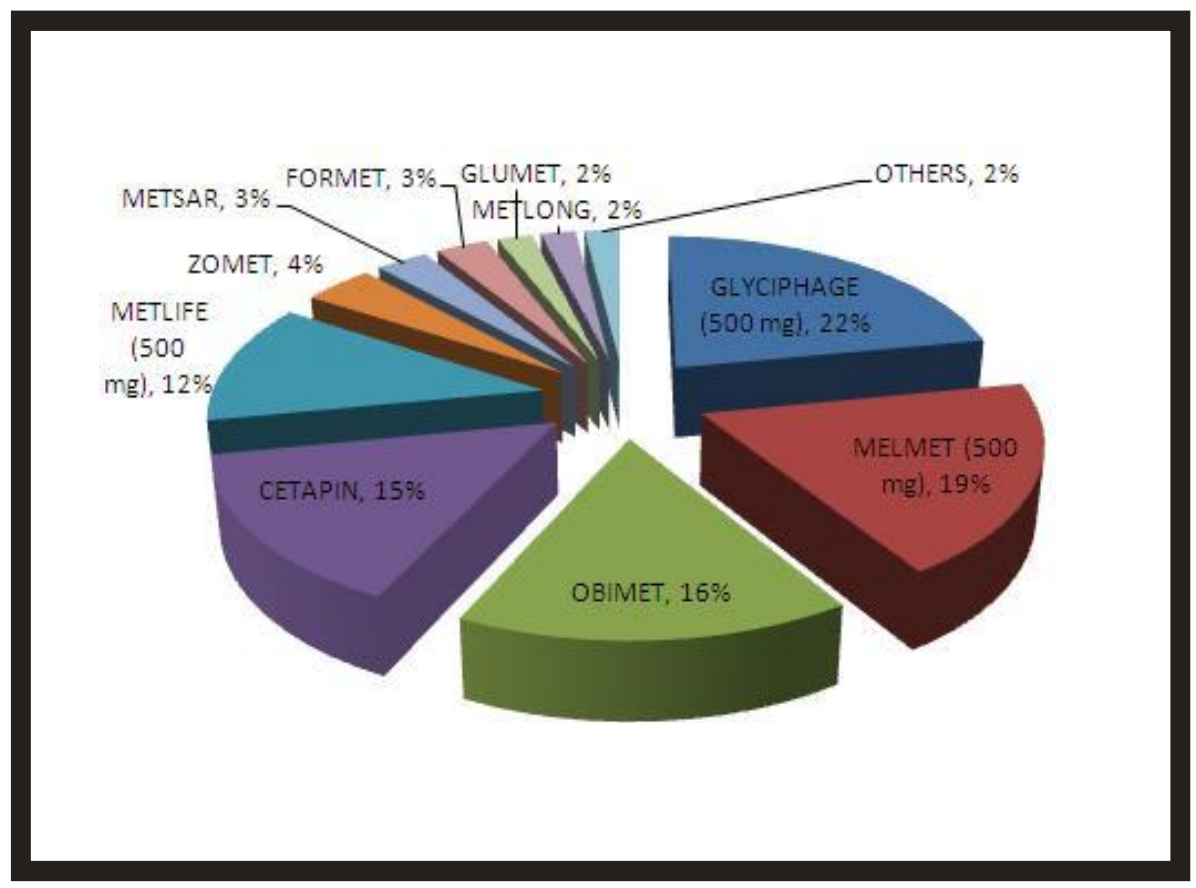

Figure 4: Pharmacist in-charge report on branded products of Metformin only 
Table 1: Questionnaire for the physician

\begin{tabular}{|l|l|}
\hline \multicolumn{2}{|c|}{$\begin{array}{c}\text { APPENDIX 1 } \\
\text { PHARMACEUTICAL MARKETING REPORT: } \\
\text { "Physician opinion on diabetes Mellitus and Metformin and its } \\
\text { Combinations" }\end{array}$} \\
\hline $\mathbf{1}$ & How many patients are coming to OPD in a day? \\
\hline $\mathbf{2}$ & How many patients are suffering from Diabetes Mellitus? \\
\hline $\mathbf{3}$ & How many patients are suffering from Type-2 Diabetes? \\
\hline $\mathbf{4}$ & How many of them are new patients? \\
\hline $\mathbf{5}$ & What is your choice of drug to treat type-2 Diabetes? \\
\hline $\mathbf{6}$ & What are the concerns associated with Diabetes in your practice regarding quality of life? \\
\hline $\mathbf{7}$ & What are the psychological impacts of diabetes on the life of diabetic patient? \\
\hline $\mathbf{8}$ & Do you prescribe Metformin and its combinations? \\
\hline $\mathbf{9}$ & If yes, then what are their brand names? \\
\hline $\mathbf{1 0}$ & Do you prescribe generics over branded drugs? \\
\hline
\end{tabular}

Table 2: Report from Pharmacist in-charge on brands having only metformin

\begin{tabular}{|l|l|l|l|}
\hline \multicolumn{5}{|c|}{$\begin{array}{c}\text { PHARMACEUTICAL MARKETING REPORT: } \\
\text { Pharmacist in-charge report about the Metformin and its combinations } \\
\text { (Brands having only Metformin) }\end{array}$} \\
\hline \multicolumn{5}{|c|}{} & Company & Strength \\
\hline S.No. & Brand & Zydus Cadila Healthcare Ltd & $500 \mathrm{mg}, 1000 \mathrm{mg}$ \\
\hline $\mathbf{1}$ & Bigesens & Sanofi Aventis & $500 \mathrm{mg}$ \\
\hline $\mathbf{2}$ & Cetapin & Biochem Pharmaceutical Industrial Ltd & $500 \mathrm{mg}$ \\
\hline $\mathbf{3}$ & Duomet ER & IPCA Laboratories Ltd & $250 \mathrm{mg}, 500 \mathrm{mg}, 850 \mathrm{mg}$ \\
\hline $\mathbf{4}$ & Emnorm & Cipla Limited & $500 \mathrm{mg}$ \\
\hline $\mathbf{5}$ & Exermet & Alkem Laboratories Ltd & $850 \mathrm{mg}$ \\
\hline $\mathbf{6}$ & Formet & Alkem Laboratories Ltd & $500 \mathrm{mg}$ \\
\hline $\mathbf{7}$ & Formin & Alembic Chemical Works Co Ltd & $500 \mathrm{mg}, 850 \mathrm{mg}, 1000 \mathrm{mg}$ \\
\hline $\mathbf{8}$ & Forminal, Forminal SR & Cipla Limited & $500 \mathrm{mg}, 850 \mathrm{mg}$ \\
\hline $\mathbf{9}$ & Glumet, Glumet EXT & Franco Indian Remedies & $250 \mathrm{mg}, 500 \mathrm{mg}$ \\
\hline $\mathbf{1 0}$ & Glyciphage, Glyciphage SR & Emcure Pharmaceuticals Ltd. & $500 \mathrm{mg}, 1000 \mathrm{mg}$ \\
\hline $\mathbf{1 1}$ & Glyrep, Glyrep XL & Cadila Pharmaceuticals Ltd. & $500 \mathrm{mg}, 850 \mathrm{mg}$ \\
\hline $\mathbf{1 2}$ & Insumet, Insumet SR & DTF (Micro Labs Ltd) & $500 \mathrm{mg}$ \\
\hline $\mathbf{1 3}$ & Melmet, Melmet SR & Sarabhai Piramal Pharmaceutical Ltd & $500 \mathrm{mg}, 850 \mathrm{mg}$ \\
\hline $\mathbf{1 4}$ & Metica & Mankind Pharmaceuticals Pvt. Ltd & $500 \mathrm{mg}$ \\
\hline $\mathbf{1 5}$ & Metlife - 500 & Panacea Biotec Ltd & $500 \mathrm{mg}$ \\
\hline $\mathbf{1 6}$ & Metlong -DS & Unichem Laboratories Ltd. & $500 \mathrm{mg}$ \\
\hline $\mathbf{1 7}$ & Metsar SR & Abbott India Ltd & $500 \mathrm{mg}$ \\
\hline $\mathbf{1 8}$ & Obimet & Cipla Limited & $500 \mathrm{mg}$ \\
\hline $\mathbf{1 9}$ & Okamet & Piramal Healthcare & $500 \mathrm{mg}$ \\
\hline $\mathbf{2 0}$ & Zomet, Zomet SR & & \\
\hline & & & \\
\hline
\end{tabular}




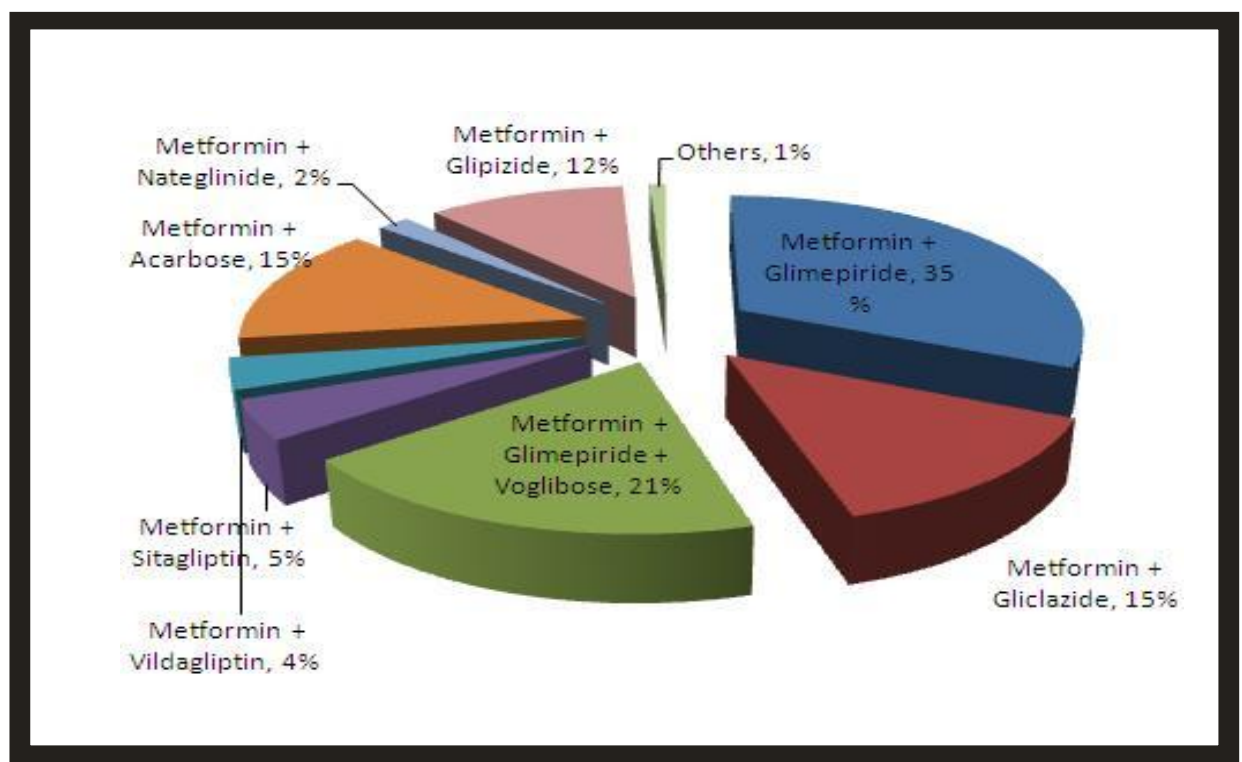

Figure 5: Pharmacist in-charge report on branded products of Metformin and its combinations.

Table 3: Report from Pharmacist in-charge on brands having only metformin and its combination

\begin{tabular}{|c|c|c|c|}
\hline \multicolumn{4}{|c|}{ APPENDIX 3} \\
\hline \multicolumn{4}{|c|}{$\begin{array}{l}\text { PHARMACEUTICAL MARKETING REPORT: } \\
\text { Pharmacist in-charge report about the Metformin and its combinations } \\
\text { (Brands having only Metformin and its combination) }\end{array}$} \\
\hline S.No & Brand & Combination strength & Company \\
\hline 1 & Glimulin-MF & Glimepiride $1 \mathrm{mg}$, Metformin $500 \mathrm{mg}$ - SR & Glenmark \\
\hline 2 & Glimulin-MF Forte & Glimepiride $2 \mathrm{mg}$, Metformin $\mathrm{HCl}$ (SR) $500 \mathrm{mg}$ & Glenmark \\
\hline 3 & Glinate-MF & Nateglinide $60 \mathrm{mg}$, Metformin $500 \mathrm{mg}$ & Glenmark \\
\hline 4 & Amaryl-M & Glimepiride 1mg, Metformin XR 500mg & Sanofi Aventis \\
\hline 5 & Amaryl-M 2 & Glimepiride 2mg, Metformin (XR) 500mg & Sanofi Aventis \\
\hline 6 & Amaryl-M Forte & Glimepiride $1 \mathrm{mg}$, Metformin $1000 \mathrm{mg}$ & Sanofi Aventis \\
\hline 7 & Amaryl-M Forte & Glimepiride $2 \mathrm{mg}$, Metformin $1000 \mathrm{mg}$ & Sanofi Aventis \\
\hline 8 & Diapride-M 1 & Glimepiride $1 \mathrm{mg}$, Metformin $500 \mathrm{mg}$ & Micro Labs Ltd \\
\hline 9 & Azukon-M & Gliclazide 80mg, Metformin $\mathrm{HCl} 500 \mathrm{mg}$ & Torrent \\
\hline 10 & Azulix-MF & Glimepiride 1mg, Metformin HCI $500 \mathrm{mg}$ & Torrent \\
\hline 11 & Azulix-MF & Glimepiride 2mg, Metformin HCI $500 \mathrm{mg}$ & Torrent \\
\hline 12 & Azulix-MF Forte & Glimepiride 1mg, Metformin HCI $1000 \mathrm{mg}$ & Torrent \\
\hline 13 & Azulix-MF Forte & Glimepiride 2mg, Metformin HCI $1000 \mathrm{mg}$ & Torrent \\
\hline 14 & Betaglim-M1 & Glimepiride $1 \mathrm{mg}$, Metformin HCI (in Extended release form) $500 \mathrm{mg}$ & Panacea \\
\hline 15 & Betaglim-M2 & Glimepiride $2 \mathrm{mg}$, Metformin $\mathrm{HCI}$ (in Extended release form) $500 \mathrm{mg}$ & Panacea \\
\hline 16 & Betagrim-M & Glimepiride $1 \mathrm{mg}$, Metformin $500 \mathrm{mg}$ & Panacea \\
\hline 17 & Betagrim-M & Glimepiride $2 \mathrm{mg}$, Metformin $500 \mathrm{mg}$ & Panacea \\
\hline 18 & Daonil-M & Glibenclamide 5mg, Metformin (XR) 500mg & Sanofi Aventis \\
\hline 19 & Daorid-M & Glibenclamide $5 \mathrm{mg}$, metformin $500 \mathrm{mg}$ & Intas \\
\hline 20 & Diaglip-M & Glipizide 5mg, Metformin $500 \mathrm{mg}$ & Cipla \\
\hline 21 & Diatrol-M & Gliclazide 80mg, Metformin $500 \mathrm{mg}$ & Aurobindo \\
\hline 22 & Dibimet Plus & Glipizide 5mg, Metformin HCI 500 mg & Novartis \\
\hline 23 & Geminor-M & Glimepiride $1 \mathrm{mg}$, Metformin $500 \mathrm{mg}$ & Macleods \\
\hline 24 & Glimy-M & Glimepiride $2 \mathrm{mg}$, Metformin $\mathrm{HCl} 500 \mathrm{mg}$ & Dr. Reddy's \\
\hline 25 & Janumet & Metformin $\mathrm{HCl} 500 \mathrm{mg}$, Sitagliptin $50 \mathrm{mg}$ & Merck \\
\hline 26 & Glucobay M25 & Acarbose $25 \mathrm{mg}$, Metformin $\mathrm{HCl} 500 \mathrm{mg}$ & Bayer \\
\hline 27 & Glucobay M50 & Acarbose $50 \mathrm{mg}$, Metformin $\mathrm{HCl} 500 \mathrm{mg}$ & Bayer \\
\hline 28 & Galvumet & Vildagliptin $50 \mathrm{mg}$, Metformin $\mathrm{HCl} 1000 \mathrm{mg}$ & Novartis \\
\hline 29 & Vogli M 0.2 & Voglibose $0.2 \mathrm{mg}$, Metformin $\mathrm{HCl} 500 \mathrm{mg}$ & $\begin{array}{l}\text { Medley Pharm. } \\
\text { ltd }\end{array}$ \\
\hline 30 & Vogli GM 2 & Voglibose $0.3 \mathrm{mg}$, Metformin $\mathrm{HCl} 500 \mathrm{mg}$, Glimepiride $2 \mathrm{mg}$ & $\begin{array}{l}\text { Medley Pharm } \\
\text { ltd }\end{array}$ \\
\hline
\end{tabular}




\section{STUDY LIMITATION}

The study gives an idea about the collaboration of Doctor-pharmacist. However, it has some limitations. The sample size is small which provides a brief idea. To increase precision, the sample size may be increased.

\section{CONCLUSION}

The global burden of diabetes is increasing worldwide as it is a costly disease for developing economies of the world. While many pharmaceutical companies have successfully deployed a plethora of strategies to target the various customer types, recent business and customer trends are creating new challenges and opportunities for increasing profitability. In the pharmaceutical and healthcare industries, a complex web of decision-makers determines the nature of the transaction (prescription) for which direct customer of pharma industry (doctor) is responsible. Essentially, the

\section{REFERENCES}

1. Oakley W. Transactions of the Medical Society of London 1962; 78: 16.

2. King H, Aubert RE, Herman WH. Global burden of diabetes, 1995-2025: prevalence, numerical estimates, and projections. Diabetes Care 1998; 21: 1414-1431.

3. Diabetes is a popular disease of the 21st century [online] [cited 2015 April 02]. Available from: URL: http://women.programming4.us/health/diabetes-is-a-populardisease-of-the-21st-century.aspx\#eYbdcrzVS8gz6Ze2.99

4. Gan D. Diabetes atlas. 3rd ed. Belgium: International Diabetes Federation; 2006.

5. Diabetes [online] [cited 2015 April 04]. Available from: URL: http://www.who.int/mediacentre/factsheets/fs $312 / \mathrm{en} /$

6. World Health Organization. Global Health Estimates: Deaths by Cause, Age, Sex and Country, 2000-2012. Geneva, WHO, 2014. end-user (patient) consumes a product and pays the cost. During the process of task we have extracted out that Diabetes Mellitus found to be an epidemic disease among the population of India. Glyciphage, Melmet And Obimet were the brands of the Metformin only, Metformin: Glimepiride, Metformin: Glimepiride: Voglibose and Metformin: Gliclazide, respectively categories which were in highest sale in the area of interest.

\section{CONFLICTS OF INTEREST}

The Authors confirm that this article has no conflicts of interest.

\section{ACKNOWLEDGEMENT}

The authors express their sincere thanks to Prof. R.M. Dubey, Vice Chancellor, IFTM University, Moradabad, Uttar Pradesh, India, for his constant encouragement to carry out the research work.

7. Mathers CD, Loncar D. Projections of global mortality and burden of disease from 2002 to 2030. PLoS Med 2006; 3(11): e442.

8. Ozougwu, JC, Obimba KC, Belonwu CD, Unakalamba CB. The pathogenesis and pathophysiology of type 1 and type 2 diabetes mellitus. J Physiol Pathophysiol 2013; 4(4): 46-57.

9. Pharmaceutical Marketing [online] [cited 2015 April 02]. Available from: URL: en.wikipedia.org/wiki/Pharmaceutical_marketing

10. Itkar SC. Pharmaceutical management. 2nd ed. Pune: Nirali Prakashan; 2006.

11. Chandra P, Kumar U, Kishore K, Ghosh AK, Sachan N. Pharmaceutical marketing investigation of pioglitazone and its combinations used for diabetes mellitus in Moradabad and Bareilly districts of UP. Indian Journal of Drugs 2013; 1(2): 42-47. 